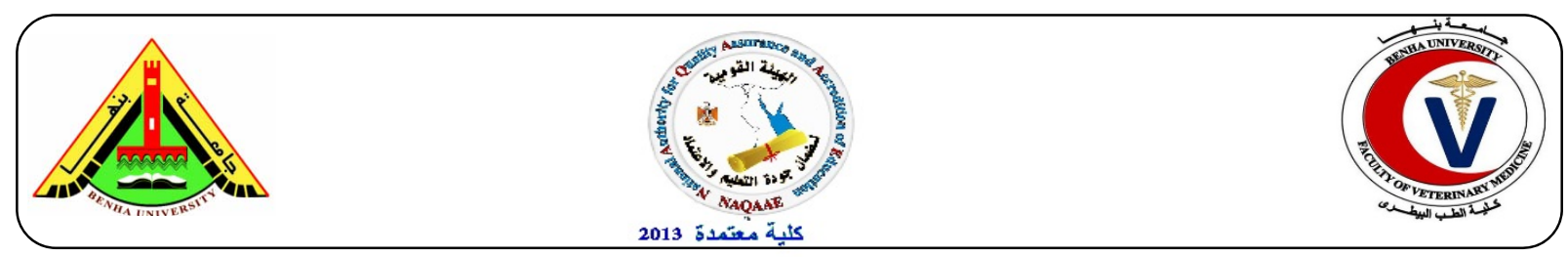

\title{
Mycotic quality of locally manufactured smoked herring fish
}

\author{
Ibrahim-Hemmat M. ${ }^{1}$, Rasha A. El Sabagh ${ }^{1}$, Abou El-Roos-NahlaA. ${ }^{2}$, Abd El kareem-mohebat ${ }^{2}$ \\ ${ }^{1}$ Department of food Hygiene, Fac. Vet. Med, Benha University, ${ }^{2}$ Food Hygiene Dept., Animal Health Research Institute \\ Shebin El-Kom branch.
}

\section{A B S T R A C T}

A grand total of 90 random samples of smoked herring fishes (30 Un packed -30 packed - 30 fillet) were collected from different markets at Monofia governorate. The samples were subjected to mycological examination for count, isolation and identification of mould and yeast. Also Molecular identification of aflatoxinogenic A. flavus was carried out. The incidence of mould in the examined samples (unpacked, packed and fillet) were $100 \%, 83.3 \%$ and $66.7 \%$, respectively. While the incidence of yeast in the examined samples (unpacked, packed and fillet) were $90 \%, 66.7 \%$ and $33.3 \%$, respectively. The mean total mould counts $/ \mathrm{g}$ was $1.9 \times 10^{5}, 2.1 \times 10^{4}, 2.5 \times 10^{3}$ for unpacked, packed and fillets, respectively. The mean total yeast counts/g was $1.7 \times 10^{5}, 2.1 \times 10^{4}, 1.3 \times 10^{2}$, respectively. The results indicated that un packed smoked herring fish were more contaminated with mould and yeast. Molecular identification of aflatoxinogenic A. Flavus was positive for three sets of different virulence genes (omtA, ver-1, and nor-1) which involved in aflatoxin biosynthetic pathway.

Keywords: Smoked herring, Mycotoxins, Aflatoxin biosynthesis, Aspergillus flavus.

(http://www.bvmj.bu.edu.eg)

(BVMJ-32(1): 113-120, 2017)

\section{INTRODUCTION}

Fish and fish products considered as a preferable source of nutritional values and highly desirable food due to its good quality animal protein content as its exceptional richness in phosphorus and calcium and its generous supply of ß- complex vitamins (Atef et al., 2011; El-AhlRasha, 2010). Traditional fish products (TFPs) which usually produced by using old preserving methods such as salting, fermenting, drying and smoking greatly varies among the countries as well as within the same country by using many different applications such as differences in percentages of salt or vinegar, additives and maturing temperatures (Sevim, 2010). Smoked herring fish is the most important processed fish products in Egypt, also known as "renga" which is commercially produced by using three main steps, the first step dry salting with $\mathrm{NaCl}$, the second step is partially air drying and the final step is smoking whether by using hot or cold smoking (Atef, 2013). Fungal contamination of fish is considered as the main cause of signs of spoilage as unpalatable taste and off flavor and it may constitute a public health hazard as well as many of economic losses (Hassan et al., 2009). Fungal infection leads to food spoilage such as discoloration, off-flavors, rotting and disintegration of the food structure (Martin et al., 2005). The very important aspect involved in spoilage of food by fungi is also the formation of toxic secondary metabolites -mycotoxins. Concerning the importance and diversity of their toxic effects (carcinogenic, mutagenic, nephrotoxic, immunotoxic, neurotoxic, teratogenic and hepatotoxic). The occurrence of mycotoxinogenic moulds in foods constitutes a high risk for animal and human health (Dalie et al., 2010; Sulyok et al., 2010; Tournas et al., 2011). Many genes involved in the biosynthesis of these mycotoxins have been identified and their DNA sequences have been published. PCR methods for the detection of aflatoxigenic Aspergilli based on the norsolorinic acid reductase encoding gene nor1 , the sterigmatocystin O-methyl transferase encoding gene omt $\mathrm{A}$, the versicolorinA dehydrogenase encoding gene ver-1 and the regulatory gene $a f l R$ have been described (Chen et al., 2002). Detection of aflatoxin producing Aspergillus species based on nor-1, ver-1 and omt1 genes by PCR system were reported by Geisen (1998).

Therefore, the aim of this work was evaluation of mycotic quality of locally manufactured smoked herring using mould and yeast count and PCR for 
detection of toxigenic genes characterization of Aspergillus flavus that could produce aflatoxin.

\section{MATERIAL AND METHODS}

\subsection{Sample}

A grand total of 90 sample of locally produced smoked herring fish were randomly sampled and Purchased from different marketing sites (30 un packed -30 packed -30 fillets) ten gram from each sample. These samples were examined mycologically according to APHA (American Public Health Association) (1992) and total mould and yeast count were detected according to Cruickshank et al. (1975) on Sabouraud's dextrose agar medium then identified macroscopically, microscopically, morphologically and physiologically according to Dvorac and Atcenasek (1969) \& Atcenasek, (1969) ; Finegold and martin (Finegold and Martin, 1982)e,(1982) and Harrigan (Harrigan and McCance, 1976) \& McCance, (1976).

\subsection{Polymerase Chain Reaction (PCR)}

For identification of virulence genes for characterization of Aspergillus flavus (Rodrigues (Rodrigues et al., 2007) et al., 2007). Table (A) shows primer sequences used for PCR identification system

\subsubsection{DNA amplification for the selected virulent genes (Davari (Davari et al., 2015) et al., 2015):}

The amplification was performed on a Thermal Cycler (Master cycler, Eppendorf, Hamburg, Germany). A total of 35 cycles was started with heating at $94^{\circ} \mathrm{C}$ for $5 \mathrm{~min}$, and continued by denaturation for 30 secs at $94^{\circ} \mathrm{C}$, annealing for 30 secs at $67^{\circ} \mathrm{C}$, elongation for 30 secs at $72^{\circ} \mathrm{C}$ and a final extension of $10 \mathrm{~min}$ at $72^{\circ} \mathrm{C}$. Amplified products were electrophoresed in $1 \%$ agarose gel (Sigma -USA) stained with ethidium bromide and visualized and captured on UV trans-illuminator. A 100 bp DNA ladder was used as a marker for PCR products.

\section{RESULTS}

Table (1) show that the Incidence of mould in the examined samples (unpacked, packed and fillet) were $30(100 \%), 25(83.3 \%), 20(66.7 \%)$, respectively. Table (2) show that the Incidence of yeast in the examined samples (unpacked, packed and fillets) were 27 (90\%), 20 (66.7\%), $10(33.3 \%)$, respectively. Table (1) show that the mean total mould counts /g were $1.9 \times 10^{5}, 2.1 \times 10^{4}, 2.5 \times 10^{3}$ for un packed, packed and fillets fish samples, respectively. Table (2) show that mean total yeast counts $/ g$ were $1.6 \times 10^{5}, 2.1 \times 10^{4}, 1.3 \times 10^{2}$ respectively.

Table ( $3 \& 4$ ) show that $80 \%$ of examined un packed smoked herring fish samples were contaminated with Aspergillus species, which represent as [A. flavus 7 isolates $(23.3 \%)$, A. niger 6 isolates (20\%) A. fumigatus 2 isolates (6.7). A. ruber 2 isolates $(6.7 \%)$, A. versicolor 1 isolate (3.3\%), A. nidulans 1 isolate (3.3), A. ochraceus 2 isolates $(6.7 \%)$, A. terrus 3 isolates (10\%)]. 50\% of the examined smoked herring fish were contaminated with Pencillium species. Mucor, Cladosporium, Rhizopus, Fusarium, Alternaria were isolated from the examined sample in different percentage of $20 \%, 13.3 \%, 10 \%, 6.7 \%$, $6.7 \%$ respectively.

For yeast species $33.3 \%$ of unpacked smoked herring fish samples were contaminated with Rhodotorula spp., Candida spp. and Saccharomyces spp. were present in the same percentage of $(16.7 \%)$. Meanwhile, Torulopsis spp., Trichosporum spp., Nigrospora spp. were isolated from the examined sample in different percentage of $13.3 \%, 10 \%, 6.7 \%$, respectively. $46.6 \%$ of examined packed Smoked herring fish samples were contaminated with Aspergillus species, which represent as $[A$. flavus 5 isolates (16.7\%), A. niger6 isolates (20\%), A. fumigatus 1 isolate (3.3\%), A. terrus 2 isolates $(6.7 \%)$ ], While $26.6 \%$ of the examined smoked herring fish were contaminated with Pencillium species. Mucor, Cladosporium, Rhizopus, Fusarium, Alternaria were isolated from the examined sample in different percentage of $16.6 \%, 10 \%, 10 \%, 3.3 \%$, $10 \%$ respectively. For yeast species $30 \%$ of packed smoked herring fish samples were contaminated with Rhodotorula spp., Candida spp. and Saccharomyces spp. were present in the same percentage of $(13.3 \%)$. Also Torulopsis spp. and Trichosporum spp. were isolated from the examined sample in the same percentage of $10 \%$. Also Hani (2014) isolated Aspergillus spp., Penicillum spp., Cladosporium spp., Rhizopus spp. and Mucor spp. from packaged smoked herring fish in percentage of $44 \%, 4.0 \%, 32 \%, 28 \%, 22 \%$ respectively.

Also $56.6 \%$ of examined fillets Smoked herring fish samples were contaminated with Aspergillus species which represent as [A. flavus 5 isolates (16.7\%), A. niger7 isolates $(23.3 \%)$, A. fumigatus 2 isolates (6.7), A. ruber 1 isolates (3.3\%), A. nidulans 1 isolate (3.3), A. terrus 1 isolates (3.3\%)]. 
Table (A) Primer sequences used for PCR identification system:

\begin{tabular}{llcll}
\hline Primer & Target gene & Oligonucleotide sequence $\left(5^{\prime} \rightarrow 3^{\prime}\right)$ & Product size $(\mathrm{bp})$ & References \\
\hline nor-1 (F) & aflD & 5' ACCGCTACGCCGGCACTCTCGGCAC '3 & & \\
nor-1 (R) & & 5' GTTGGCCGCCAGCTTCGACACTCCG '3 & 400 & \\
ver-1 (F) & & 5' GCCGCAGGCCGCGGAGAAAGTGGT '3 & \\
ver-1 (R) & aflM & 5' GGGGATATACTCCCGCGACACAGCC '3 & 537 & (Criseo et al., 2001) \\
omtA (F) & & 5' GTGGACGGACCTAGTCCGACATCAC '3 & & \\
omtA (R) & aflP & 5' GTCGGCGCCACGCACTGGGTTGGGG '3 & 797 & \\
\hline
\end{tabular}

Table (1): Incidence of mould species isolated from the examined smoked herring fish samples $(\mathrm{n}=30)$.

\begin{tabular}{lcccccc}
\hline Samples & No. of $^{+}$ve Samples & \% of ${ }^{+}$ve Samples & Min & Max. & Mean & S.D. \\
\hline Un packed & 30 & 100 & $1.9 \times 10^{3}$ & $9.8 \times 10^{5}$ & $1.9 \times 10^{5}$ & $2.8 \times 10^{5}$ \\
Packed & 25 & 83.3 & $2.7 \times 10^{2}$ & $8.2 \times 10^{4}$ & $2.1 \times 10^{4}$ & $2.6 \times 10^{4}$ \\
Fillets & 20 & 66.7 & $4.2 \times 10^{3}$ & $9.5 \times 10^{3}$ & $2.5 \times 10^{3}$ & $3.6 \times 10^{3}$ \\
\hline
\end{tabular}

N.B: Percentage were calculated according to total no. of samples $n=30$

Table (2): Incidence of yeast species isolated from the examined smoked herring fish samples $(\mathrm{n}=30)$.

\begin{tabular}{lcccccc}
\hline Samples & No. of $^{+}$ve Samples & $\%^{\text {of }}{ }^{+}$ve Samples & Min. & Max. & Mean & S.D. \\
\hline Un packed & 27 & 90 & $1.3 \times 10^{3}$ & $8.4 \times 10^{5}$ & $1.6 \times 10^{5}$ & $2.5 \times 10^{5}$ \\
Packed & 20 & 66.7 & $2.6 \times 10^{2}$ & $9.2 \times 10^{4}$ & $2.1 \times 10^{4}$ & $3.1 \times 10^{4}$ \\
Fillets & 10 & 33.3 & $3.8 \times 10$ & $5.6 \times 10^{2}$ & $1.3 \times 10^{2}$ & $1.6 \times 10^{2}$ \\
\hline
\end{tabular}

Table (3): classification of moulds species isolated from the examined Smoked fish samples and their incidence (unpacked, packed, fillet) $(\mathrm{n}=30)$.

\begin{tabular}{|c|c|c|c|c|c|c|}
\hline \multirow{3}{*}{ Mould species } & \multicolumn{2}{|c|}{ Un packed } & \multicolumn{2}{|l|}{ packed } & \multicolumn{2}{|c|}{ Fillets } \\
\hline & No. of + ve & & No. of & & No. of + ve & \\
\hline & Samples & $\%$ & Samples & $\%$ & Samples & $\%$ \\
\hline Aspergillus spp.: & 28 & $80 \%$ & 14 & $46.6 \%$ & 17 & $66.6 \%$ \\
\hline A. flavus & 7 & $23.3 \%$ & 5 & $16.7 \%$ & 5 & $16.7 \%$ \\
\hline A. niger & 6 & $20 \%$ & 6 & $20 \%$ & 7 & $23.3 \%$ \\
\hline A. ochraceus & 2 & $6.7 \%$ & 0 & $0 \%$ & 0 & $0 \%$ \\
\hline A. fumigates & 2 & $6.7 \%$ & 1 & $3.3 \%$ & 2 & $6.7 \%$ \\
\hline A .ruber & 2 & $6.7 \%$ & 0 & $0 \%$ & 1 & $3.3 \%$ \\
\hline A.terrus & 3 & $10 \%$ & 2 & $6.7 \%$ & 1 & $3.3 \%$ \\
\hline A.nidulanc & 1 & $3.3 \%$ & 0 & $0 \%$ & 1 & $3.3 \%$ \\
\hline A.versicolor & 1 & $3.3 \%$ & 0 & $0 \%$ & 0 & $0 \%$ \\
\hline Penicilliumspp & 15 & $50 \%$ & 8 & $26.6 \%$ & 5 & $16.6 \%$ \\
\hline Mucorspp & 6 & $20 \%$ & 5 & $16.7 \%$ & 4 & $13.3 \%$ \\
\hline Cladosporiumspp & 4 & $13.3 \%$ & 3 & $10 \%$ & 2 & $6.7 \%$ \\
\hline Rhizopusspp & 3 & $10 \%$ & 3 & $10 \%$ & 1 & $3.3 \%$ \\
\hline Fusariumspp & 2 & $6.7 \%$ & 1 & $3.3 \%$ & 1 & $3.3 \%$ \\
\hline Alternariaspp & 2 & $6.7 \%$ & 3 & $10 \%$ & 1 & $3.3 \%$ \\
\hline
\end{tabular}


Table (4): classification of yeast species isolated from the examined Smoked fish samples and their incidence (unpacked, packed, fillet) $(\mathrm{n}=30)$.

\begin{tabular}{|c|c|c|c|c|c|c|c|c|c|}
\hline \multirow[b]{2}{*}{ Yeast species } & \multicolumn{3}{|l|}{ Un packed } & \multicolumn{3}{|l|}{ packed } & \multicolumn{3}{|l|}{ Fillets } \\
\hline & $\begin{array}{l}\text { No. of } \\
\text { Samples }\end{array}$ & $+\mathrm{ve}$ & $\%$ & $\begin{array}{l}\text { No. of } \\
\text { Samples }\end{array}$ & $+\mathrm{ve}$ & $\%$ & $\begin{array}{l}\text { No. of } \\
\text { Samples }\end{array}$ & $+\mathrm{ve}$ & $\%$ \\
\hline Rhodotrula spp. & 10 & & $33.3 \%$ & 9 & & $30 \%$ & 2 & & $6.7 \%$ \\
\hline Candida spp. & 5 & & $16.7 \%$ & 4 & & $13.3 \%$ & 1 & & $3.3 \%$ \\
\hline $\begin{array}{l}\text { Saccharomyces } \\
\text { spp. }\end{array}$ & 5 & & $16.7 \%$ & 4 & & $13.3 \%$ & 0 & & $0 \%$ \\
\hline Torulopsis spp. & 4 & & $13.3 \%$ & 3 & & $10 \%$ & 1 & & $3.3 \%$ \\
\hline Trichosporum spp. & 3 & & $10 \%$ & 3 & & $10 \%$ & 2 & & $6.7 \%$ \\
\hline Nigrospora spp. & 2 & & $6.7 \%$ & 0 & & $0 \%$ & 0 & & $0 \%$ \\
\hline
\end{tabular}

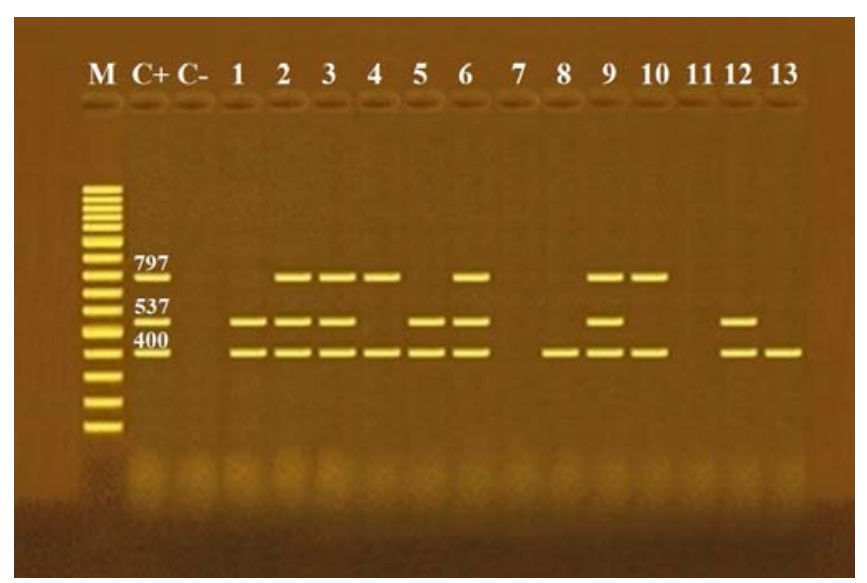

Fig. (1): Agarose gel electrophoresis of multiplex PCR of nor-1 (400 bp), ver-1 (537 bp) and omtA (797 bp) virulence genes for characterization of Aspergillus flavus. Lane M: $100 \mathrm{bp}$ ladder as molecular size DNA marker. Lane C+: Control positive strain for nor-1, ver-1 and omtA genes. Lane C-: Control negative. Lanes 1,2,3, 5,6,9\&12: Positive A. flavus strains for nor-1 and ver-1 genes. Lanes 2, 3, 6 \& 9: Positive A. flavus strains for nor-1, ver-1 and omtA genes. Lane 4 \& 10: Positive A. flavus strains for nor-1 and omtA genes. Lane 8 \& 13: Positive A. flavus strains for nor-1 gene. Lanes 7 \& 11: Negative A. flavus strains for nor-1, ver-1 and omtA genes.

While $16.6 \%$ of the examined smoked herring fish were contaminated with Pencillium species. Mucor, Cladosporium were isolated from the examined sample in different percentage of $13.3 \%$, $6.7 \%$ respectively. Rhizopus, Fusarium, Alternaria isolated in the same percentage $3.3 \%$. For yeast species $6.7 \%$ of fillets smoked herring fish samples were contaminated with Rhodotorula spp., Candida spp., Torulopsis spp., Trichosporum spp., were isolated from the examined sample in different percentage of $3.3 \%, 3.3 \%, 6.7 \%$ respectively. Fig. (1) showing positive result for omt- $A$, ver-1 and nor-1 coding genes for the key enzymes in aflatoxin B1 biosynthesis.

\section{DISCUSSION}

Herring as a food vehicle is subjected to contamination with variable genera and species of mould and yeast, therefore the preventive and strictly measures of significant concern intended to eradicate or at least to minimize this contamination or its hazard effects to protect human from consuming the ready-to-eat smoked herring from the probable danger of both acute and chronic toxic effects (Mounir et al., 2011).

Many strains of moulds were recorded to constitute a public health hazard due to mycotoxin production such as aflatoxin, ochratoxin, patulin and zearalenone (Hassan et al., 2009). Which have carcinogenic effect, the high mycotoxins levels could lead to liver cancer while subacut levels are responsible for liver diseases and organs damage (Youssef, 1998).

It is evident from data present in table (1) that the Incidence of mould in the examined samples (unpacked, packed and fillet) were $30(100 \%), 25$ $(83.3 \%), 20(66.7 \%)$ respectively. While it is evident from data present in table (2) that the 
Incidence of yeast in the examined samples (unpacked, packed and fillets) were $27(90 \%), 20$ $(66.7 \%), 10(33.3 \%)$ respectively. The results obtained are nearly similar to those obtained by ElSayed (1995). Lower results were obtained by Abd El- Maksoud et al. (2010). While Edris et al. (2012) et al., (2012) reported that the rate of mycotic contamination in the examined Vacuumed packed herring $52 \%$ and $68 \%$ for fillet and negative yeast. It is evident from data present in table (1) that the mean total mould counts /g were $1.9 \times 10^{5}, 2.1 \times 10^{4}$, $2.5 \times 10^{3}$ for unpacked, packed and fillets fish samples respectively. Table (2) show that mean total yeast counts $/ \mathrm{g}$ were $1.6 \times 10^{5}, 2.1 \times 10^{4}$, $1.3 \times 10^{2}$ These results were nearly similar to results obtained by Adebayo-Tayo et al. (2008); El-Sayed (1995); El-Shater (1994); El-Zahaby (2007); Mounir et al. (2011)and Hani (2014), while lower results were obtained by Abd-Eldayem-Wafaa (1999); Abd El- Maksoud et al. (2010); AwadHoda et al. (1998); Edris (1996); Ibrahim (2000); Mahmoud (2010); Safaa (1999) and Nyarko et al. (2011).

Smoked fish might be easily contaminated with mould growth specially un packed smoked herring, it may be due using contaminated salt, packaging and bad handling (Plahar et al., 1991).

It is evident from data present in table (3\&4) that $80 \%$ of examined un packed Smoked herring fish samples were contaminated with Aspergillus species, which represent as [A. flavus 7 isolates (23.3\%), A. niger 6 isolates (20\%) A. fumigatus 2 isolates (6.7). A. ruber 2 isolates (6.7\%), A. versicolor 1 isolate $(3.3 \%)$, A. nidulans 1 isolate (3.3), A. ochraceus 2 isolates $(6.7 \%)$, A. terrus 3 isolates (10\%)], While $50 \%$ of the examined smoked herring fish were contaminated with Pencillium species. Mucor, Cladosporium, Rhizopus, Fusarium, Alternaria were isolated from the examined sample in different percentage of $20 \%, 13.3 \%, 10 \%, 6.7 \%, 6.7 \%$ respectively. For yeast species $33.3 \%$ of unpacked smoked herring fish samples were contaminated with Rhodotorula spp. Candida spp. and Saccharomyces spp., were present in the same percentage of $(16.7 \%)$, Meanwhile Torulopsis spp., Trichosporum spp., Nigrospora spp. were isolated from the examined sample in different percentage of $13.3 \%, 10 \%$, $6.7 \%$ respectively. Such results are nearly similar to those obtained by Atef et al. (2011); El-Sayed (1995); El-Shater (1994); El -Gazzar et al. (2005); Mounir et al. (2011); Nayel (2007); Safaa (1999); Youssef and Farghaly (2003) and Radwa (2012). While Edris (1996) (1996) who isolated Pencillium species and Aspergillus species from the examined samples in percentage of $80 \%, 60 \%$ respectively. Also Ibrahim (2000) isolated the same species from
$70 \%, 50 \%$ of examined sample respectively., Salem (2004) isolated the same species from $58 \%$ ,48\% of examined sample respectively. Moreover Mahmoud (2010) isolated Aspergillus spp. and Penicillum spp. (50\%), (46.66\%) from smoked fish respectively. Also Hani (2014) isolated Aspergillus spp., Penicillum spp., Cladosporium spp., Rhizopus spp. and Mucor spp. from unpackaged smoked herring fish in percentage of $48 \%, 42 \%$, $38 \%, 32 \%$ and $22 \%$ respectively .

In the Egyptian markets, most of the smoked fish, are stored in wooden boxes at ordinary room temperature for a sufficient time, predisposing them to mould and yeast growth (El-Sayed, 1995). Also $46.6 \%$ of examined packed Smoked herring fish samples were contaminated with Aspergillus species, which represent as [A. flavus 5 isolates (16.7\%), A. niger 6 isolates (20\%), A. fumigatus 1 isolate $(3.3 \%)$, A. terrus 2 isolates $(6.7 \%)]$, While $26.6 \%$ of the examined smoked herring fish were contaminated with Pencillium species. Mucor, Cladosporium, Rhizopus, Fusarium, Alternaria were isolated from the examined sample in different percentage of $16.6 \%, 10 \%, 10 \%, 3.3 \%$, $10 \%$ respectively. For yeast species $30 \%$ of packed smoked herring fish samples were contaminated with Rhodotorula spp., Candida spp. and Saccharomyces spp. in the same percentage of 13.3\%. Also Torulopsis spp. and Trichosporum spp. were isolated from the examined sample in the same percentage of $10 \%$. Also Hani (2014) isolated Aspergillus spp., Penicillum spp., Cladosporium spp., Rhizopus spp. and Mucor spp. from packaged smoked herring fish in percentage of $44 \%, 4 . \%$, $32 \%, 28 \%, 22 \%$ respectively .

Also $56.6 \%$ of examined fillets Smoked herring fish samples were contaminated with Aspergillus species, which represent as [A. flavus 5 isolates (16.7\%), A. niger7 isolates (23.3\%), A. fumigatus 2 isolates (6.7), A.ruber 1 isolates (3.3\%), A. nidulans 1 isolate (3.3), A. terrus 1 isolates (3.3\%) ] ,While $16.6 \%$ of the examined smoked herring fish were contaminated with Pencillium species. Mucor, Cladosporium were isolated from the examined sample in different percentage of $13.3 \%$, $6.7 \%$ respectively. Rhizopus, Fusarium, Alternaria isolated in the same percentage $3.3 \%$. For yeast species $6.7 \%$ of fillets smoked herring fish samples were contaminated with Rhodotorula spp., Candida spp, Torulopsis spp., Trichosporum spp., were isolated from the examined sample in different percentage of $3.3 \%, 3.3 \%, 6.7 \%$ respectively. These results came in disagreement with those reported by Edris et al., (2012) who can't isolate yeast from herring fillets in jar.

Fish treated by a bad hygienic measures may be prone to contamination with microorganisms such 
as bacteria and fungi and presence of Aspergillus flavus in the samples might probably make its consumption hazardous to health (Abd ElMaksoud et al., 2010). The presence of species of Aspergillus could be attributed to the prevalence of their spores in the atmosphere (Adebayo-Tayo et al., 2009).

Unhygienic handling such as the use of old news prints, cement papers and polyethylene bags are all sources of contamination of fish, which constitute a public health hazard (Edris et al., 2012; El-Zahaby, 2007). It was evident from Fig. (1) that specific primers for A. flavus were designed based on the omt-A, ver-1 and nor-1 genes coding for the key enzymes in aflatoxin B1 biosynthesis and used to detect the fungus. Most of samples are Positive A. flavus strains for nor- 1 , ver- 1 and omtA genes. These results agree with those reported by Ebaid (2014).

The expression of aflatoxin genes has been applied for detection and differentiation of aflatoxigenic strains. so, various regulatory and structural aflatoxin pathway genes in Aspergillus parasiticus and Aspergillus flavus have been targeted (Degola et al., 2007; Scherm et al., 2005; Sweeney et al., 2000). Aflatoxins are secondary metabolites, which are produced by Aspergillus flavus, when taken by human. It could induce hepatitis and hepatic enlargement. Also are known to be carcinogenic and mutagenic (Abbas et al., 2004).

In conclusion, the obtained results in the present study indicated that unpacked smoked herring fish were more contaminated with mold and yeast. Moreover, PCR is a sensitive technique for detection of virulence genes enter in mycotoxins biosynthetic pathway. Also the present study demonstrated that unhygienic handling and improper sanitation during catching, handling, processing, storage, transportation, distribution and marketing of fish. All sources of contamination of fish constitute a public health hazard.

\section{REFERENCES}

Abbas, H.K., Shier, W.T., Horn, B.W., 2004. Cultural methods for aflatoxin detection. J Toxicol Toxin Rev. 23, 295-315.

Abd-Eldayem-Wafaa, F., 1999. Microbiological aspect of Smoked fishes at retail outlet. M.V.Sc., Fac.Vet.Med., Zagazig Univ. Egypt.

Abd El- Maksoud, S.A., El-Kuttan, A.A., Mohamed, M.E.M., 2010. Mycological Studies On Smoked Fish Marketed In Dumyat With Special Reference To Public
Health Importance. $10^{\text {th }}$ Sci. Vet. Med. Zag. Conference, Egypt.

Adebayo-Tayo, B.C., Adegoke, A.A., Akinjogunla, O.J., 2009. Microbial and physico-chemical quality of powdered soy milk samples in Akwalbom", South Southern Nigeria. African Journal of Biotechnology 8, 3066-3071.

Adebayo-Tayo, B.C., Onllude, A.A., Patrick, G.U., 2008. Mycofloral of Smoked-Dried Fish soldin Uyo", Eastern Nigeria World Journal of AgriculturalSciences 4, 346-350.

APHA (American Public Health Association), 1992. Compendium of methods for the microbilogical examination of food. $3^{\text {rd }} \mathrm{Ed}$. American Public Health Association, Washington, D.C.

Atef, A.H., Manal , A.H., Howayda, M.E.S., Rasha, M.H.S.E.A., Abd El-Dayem, R.H., 2011. Detection of AflatoxigenicMoulds Isolated FromFish and their Products and its Public Health. Nature and Science 9, 230240.

Atef, S.O., 2013. Technological Attempts for Production of Low Sodium Smoked Herring Fish (Renga). Advance Journal of Food Science and Technology 5, 695-706.

Awad-Hoda, A., Ragheb, R.R., El- Sharnoby, R., Zienab, N., 1998. Mycological study on some kinds of processed fishes with special reference to Penicilliumspecies. Ph.D.Thesis, Dept. Food Hygiene and Control,Egypt.

Chen, R.S., Tsay, J.G., Huang, Y.F., Chiou, R.Y.Y., 2002. Polymerase chain reactionmediated characterization of molds belonging to the Aspergillusflavus group and detection of Aspergillusparasiticus in peanut kernels by a multiplex polymerase chain reaction. J. Food Protect 65, 840-844.

Criseo, G., Bagnara, A., Bisignano, G., 2001. Differentiation of aflatoxin-producing and non-producing strain of Aspergillus flavus group. J. App. Microb. 33, 291-295.

Cruickshank, R., Duguid, J.P., Marmion, B.P., Swain, R.H.A., 1975. Medical Microbiology". $12^{\text {th }}$. Ed. Churchill Livingstone Edinburgh. London, England.

Dalie, D.K.D., Deschamps, A.M., Richard-forget, F., 2010. Lactic acid bacteria - Potential for controlof mould growth and mycotoxins", A review. Food Control 21, 370-380.

Davari, E., Mohsenzadeh, M., Mohammadi, G., Shahsavandi, S., Doloei, R., 2015. 'Characterization of aflatoxigenic Aspergillus flavus and A. parasiticus strain isolates from animal feedstuffs in 
Northeastern Iran. Iranian J. Vet. Res. 16, 150-155.

Degola, F., Berni, E., Dell asta, C., Spotti, E., Marchelli, F.M., ., R., 2007. A multiplex RT-PCR approach to detectaflatoxigenic strains of Aspergillusflavus. Journal of Applied Microbiology 103, 409-417.

Dvorac, J., Atcenasek, M., 1969. Mycological diagnosis of animal dermatophytosis. Academia P. 213.

Ebaid, M.R.B., 2014. Molecular studies on certain Toxopathogenic fungi in Smoked dried and Salted fishes in Egypt. PhD. in Veterinary Medical Sciences, Dept. of Bacteriology, Mycology and Immunology, Kafrelsheikh University, Egypt.

Edris, A.M., 1996. Microbial evaluation of some marketed Smoked fish. Zag. Vet. J. 24, 7681.

Edris, A.M., Hasanena- Faten, S., Khaterb- Dalia, F., Radwa, A.L., 2012. MicrobiologicalStudies on Some Fishery Products. Benha Veterinary Medical Journal 23, 185-191.

El-Ahl- Rasha, M.H.S., 2010. Studies on fungi in fish and fishproducts and their control. PhD. Thesis, Dept. of Microb, Fac. of Vet. Med., Cairo Univ.

El-Sayed, Y.S., 1995. Mycological studies on locally produced smoked fishes with special reference to toxigenic strains. $\mathrm{PhD}$ Thesis, Meat Hygiene, Fac.Vet. Med., Zagazig Univ. Egypt.

El-Shater, M.A.H., 1994. Quality investigation into locally produced Smoked fishes. PhD Thesis, Fac. of Vet. Med. Cairo University, Egypt.

El-Zahaby, D.I.M., 2007. Microbiological and chemical studies on some fish and fish products in Menoufia Governorate. M.V.Sc.Thesis (Meat Hygiene and Control), Fac. Vet. Med. Menoufia, Egypt.

El -Gazzar, M.M.M., Hassan M.A , Farghaly, R.M., Sallam, K.I.A., 2005. Mycological and related studies on smoked fish. $4^{\text {th }}$ Int. Sci . Conf. Mansoura. Egypt, 762-793.

Finegold, S.H., Martin, W.J., 1982. Baily and Scott's Diagnostic Microbiology. $6^{\text {th }}$ C.V. Mosby Co. St. Louis, Toronto, London.

Geisen, R., 1998. PCR methods for the detection of mycotoxin producing fungi. Applications of PCR in mycology. Wallingford - $\mathrm{CAB}$ International, 243-266.

Hani, M.E.A., 2014. Criteria for evaluation of smoked herring fish. PhDThesis (Meat Hygiene and Control), Fac. Vet. Med. Alexandria. Egypt.
Harrigan, W.F., McCance, M.E., 1976. Laboratory methods in food and dairy tests in the diagnosis of human echinococcosis and follow-up. Clin Infect Dis 15, 473-480.

Hassan, A.A., Wael, M.T., Abdel Aziz, A.E., El Shafei -Howayda, M., 2009. The hepatoprotective effect of dimethyl 4,4dimethoxy5,6,5,6-dimethylenedioxy-

biphenyl - dicarbxylate(D.D.B.) against liver injury induced by aflatoxin B1 in rates, Egypt. J. of Appl. Sci. 24, 86-100.

Ibrahim, H.A.M., 2000. Incidence of fungal contaminants in fish and fish products. M.V.Sc., Thesis, Zag. Univ. Benha Branch, Egypt.

Mahmoud, R., 2010. Studies on fungi in fish and fish Products and their control. PhD Thesis dept of Microbiology Fac. Vet. Med. Cairo University, Egypt.

Martin, S., Ramos, A.J., Sanchis, V., 2005. Comparison ofmethods for the assessment of growth of foodspoilage moulds in solid substrates. Int. J. Food Microbiol 99, 329341.

Mounir, M., Salem-Bekhet, Abd Al-Azeem, M.W., Hashim, E.S.Y., 2011. Mycological Aspect of Smoked Fish atRetail Outlet at the Delta Province of Egypt. J. Appl. Environ. Biol. Sci., 1, 26-31.

Nayel, M.S., 2007. Microbilogical status of some markted canned and pickled fish. M.V.Sc. Thesis, Dept. Meat Hygiene, Fac. Vet. Med. Benha Univ, Egypt.

Nyarko, H.D., Obodai, E.A., Boamponsem, L.K., Coomson, S.S., Aniwe, Y., 2011. Microbial profile of smoked sardine (Sardilellaaurita) AT smoking sites and market centres of Tema", Ghana. Arc. Appl. Sci. Res. 3, 443453.

Plahar, W.R., Race, R.D., Lu, J.Y., 1991. Effect of storage condition on the quality of Smoked dried herring (Sardinellaeba). Journal of the Science of food and Agriculture 57, 597610.

Radwa, A.M.L., 2012. Microbilogical studies on some fish products. Master Thesis, Faculty of Vet, Med. of food control. Benha University, Egypt.

Rodrigues, S.C., Kozakiewicz, Z., Paterson, R.R.M., Lima, N., Venâncio, A., 2007. Identification and characterization of Aspergillusflavus and aflatoxins. Communicating Current Resereach and Educational Topics and Trends in Applied Microbioloy A. Méndez-Vilas (Ed.).

Safaa, S.T., 1999. Mycological contamination of some fish products at Alexanderia province. 
M.V.Sc. Thesis, Dept. Food Control. Fac. Vet. Med. Alexanderia University.

Salem, D.A.I., 2004. Microbiological profile of local smoked fish. M.V.Sc.Thesis, (Meat Hygiene), Fac. Vet. Med., Zagazig Univ. Benha Branch, Egypt.

Scherm, B.M., Palmoba, D., Serra, A.M., Migheli, Q., 2005. Detection of transcripts of the aflatoxin genes afID, afIO and afIP by revers transcription-Polymerase chains reaction allows differentiation of aflatoxin-producing and non- producing isolates of Aspergillus parasiticus. International Journal of Food Microbiology 98, 201-210.

Sevim, K., 2010. Evaluation of Seafood Safety Health Hazardsfor Traditional Fish Products, Preventive Measures and Monitoring Issues. Turkish Journal of Fisheries andAquatic Sciences 10, 139-160.

Sulyok, M., Krska, R., Schuhmacher, R., 2010. Application of an LC-MS/MS based multimycotoxinmethod for the semi-quantitative determination of mycotoxins occurring in different types of food infectedby moulds. Food Chem. 119, 408-416.

Sweeney, M.J., Pamies, P., Dobspn, A.D.W., 2000. The useof reverse transcription-polymerase chain reaction (RT- PCR) for monitoring aflatoxin production in A parasiticus. International Journal of Food Microbiology 56, 97-103.

Tournas, V.H., Rivera calo, J., Memon, S., 2011. Comparison of the SimPlate yeast and mould colorindicator to the BAM method for quantification of fungiin naturallycontaminated foods. Food Control 22, 775 777.

Youssef, H.H.E., 1998. Mycological status of Moloha, Smoked herring and frozen mackerel fish in Assuit province. $\mathrm{PhD}$ Thesis, Dept. Food Control, Fac. Vet. Med. Assiut University, Egypt.

Youssef, M.S.A.-D., Farghaly, R.M., 2003. Studies on Mycological status of salted fish (Moloha) in upper Egypt. Mycology 31, 166-172. 